\title{
Yield of onion in soil with cattle manure and nitrogen
}

\author{
Aline B. Belem ${ }^{1}$, Ademar P. de Oliveira ${ }^{1}$, Luciana M. Guimarães ${ }^{1}$, Josyelem T. L. Chaves ${ }^{2}$ \& \\ Antonio M. P. Bertino ${ }^{1}$ \\ ${ }^{1}$ Universidade Federal da Paraíba/Departamento de Fitotecnia e Ciências Ambientais, Areia, PB, Brasil. E-mail: alinebbelem@gmail.com (Corresponding \\ author) - ORCID: 0000-0001-9980-1390; ademar@cca.ufpb.br - ORCID: 0000-0003-3518-5351; lucianaguimaraesuepb@gmail.com - ORCID: 0000- \\ 0002-2367-3289; missiemario1994@hotmail.com - ORCID: 0000-0002-6598-5192 \\ ${ }^{2}$ Universidade Federal de Lavras/Departamento de Fisiologia Vegetal, Lavras, MG, Brasil. E-mail: josyelem_josy@hotmail.com - ORCID: 0000-0002- \\ 6543-3523
}

\begin{abstract}
Onion is the third vegetable crop in economic importance for Brazil, only behind potato and tomato, and responds with increased production to the use of organic and mineral fertilizers. The objective of this study was to evaluate the effect of doses of cattle manure and nitrogen $(\mathrm{N})$ on onion growth and yield. The experimental design used was randomized blocks, in $6 \times 2$ factorial scheme, corresponding to six doses of cattle manure $\left(0 ; 10 ; 20 ; 30 ; 40\right.$ and $\left.50 \mathrm{tha}^{-1}\right)$, in the presence and absence of $\mathrm{N}$, with four repetitions. The variables studied were: shoot fresh and dry masses, total and marketable bulb yields, percentage of bulbs classified and leaf $\mathrm{N}$ content. There was an interactive effect $(\mathrm{p} \leq 0.05)$ of cattle manure and $\mathrm{N}$ doses on shoot fresh and dry masses, total and marketable yields, classification of bulbs according to transverse diameter and $\mathrm{N}$ concentration in onion bulbs. The optimal dose for marketable yield of bulbs is $27 \mathrm{tha}^{-1}$ of cattle manure in the presence of $\mathrm{N}$.
\end{abstract}

Key words: Allium cepa L., organic fertilization, mineral fertilization

\section{Rendimento da cebola no solo com esterco bovino e nitrogênio}

RESUMO: A cebola é a terceira hortaliça em importância econômica para o Brasil, sendo superada apenas pela batata e o tomate, e responde com aumento de produção ao uso de adubos orgânico e mineral. Objetivou-se com este trabalho avaliar o efeito de doses de esterco bovino e nitrogênio sobre o crescimento e rendimento da cebola. O delineamento experimental utilizado foi em blocos casualizados, em esquema fatorial $6 \times 2$ correspondente a seis doses de esterco bovino $\left(0 ; 10 ; 20 ; 30 ; 40 \mathrm{e}^{5} \mathrm{tha}^{-1}\right)$, na presença e ausência do nitrogênio, em quatro repetições. Foram avaliadas as variáveis: massa verde e seca da parte aérea, produtividades total e comercial de bulbos, percentagem de bulbos classificados e teor de $\mathrm{N}$ foliar. Houve efeito interativo ( $\mathrm{p} \leq$ $0,05)$ das doses de esterco bovino e nitrogênio sobre a massa verde e seca da parte aérea, produtividades total e comercial, para a classificação de bulbos de acordo com o diâmetro transversal e o teor de $\mathrm{N}$ em bulbos de cebola. A dose ótima para produtividade comercial de bulbos é de $27 \mathrm{t} \mathrm{ha}^{-1}$ de esterco bovino na presença de nitrogênio.

Palavras-chave: Allium cepa L., fertilização orgânica, fertilização mineral 


\section{INTRODUCTION}

Onion (Allium cepa L.) is the third vegetable crop in economic importance for Brazil, only behind potato and tomato. According to data of IBGE (2013), the national production in 2013 was 1.4 million tons, and the main producers were the states of Santa Catarina and Minas Gerais. In the Northeast region, the São Francisco Valley stands out as one of the largest producers.

Onion production in Brazil is an activity practiced mainly by small producers and its socio-economic importance is based not only on profitability, but on the great demand for labor, contributing to the feasibility of small properties and maintenance of producers in the rural area, reducing migration to major cities (Resende \& Costa, 2009).

The use of cattle manure becomes a useful and economical practice for small and medium producers of vegetables (Araújo et al., 2007), which react well to this type of fertilization. The use of this input for several consecutive years promotes accumulation of organic nitrogen in the soil, increasing its mineralization potential and its availability to plants (Oliveira et al., 2010).

In onion, the absorption of nitrogen is surpassed only by that of potassium (Pôrto et al., 2007), and it is the nutrient that most affects bulb yield, health and quality (Resende et al., 2008). However, excessive quantity may limit bulb yield and increase post-harvest losses (Souza \& Resende, 2002), whereas its deficiency may reduce bulb growth rate (Rodrigues et al., 2015).

Thus, the objective of this study was to evaluate the effect of doses of cattle manure and nitrogen on onion growth and yield.

\section{Material ANd Methods}

The study was carried out under field conditions from June to November 2016, at the Universidade Federal da Paraíba (UFPB), in Areia, PB, Brejo Paraibano microregion, Brazil, with altitude of $574.62 \mathrm{~m}$, latitude of $6^{\circ} 58^{\prime} \mathrm{S}$ and longitude of $35^{\circ} 42^{\prime} \mathrm{W}$. The climate according to Köppen's classification is As', which is characterized as hot and humid, with autumnwinter rains (Gondim \& Fernandez, 1980). The average annual temperature varies between 23 and $24^{\circ} \mathrm{C}$, with average precipitation of $1200 \mathrm{~mm}$. During the experimental period, the precipitation, temperature and air relative humidity data were collected at the meteorological station of the Centro de Ciências Agrarias of UFPB.

The soil of the cultivation area was classified as Entisol. The average temperature in ${ }^{\circ} \mathrm{C}$, precipitation and air relative humidity along the experimental period were, respectively: June $=22.5^{\circ} \mathrm{C} ; 164 \mathrm{~mm} ; 88.2 \%$; July $=21.6{ }^{\circ} \mathrm{C}$; $79.6 \mathrm{~mm}$; $91 \%$; August $=21.9^{\circ} \mathrm{C} ; 68.7 \mathrm{~mm} ; 84 \%$; September $=23.3{ }^{\circ} \mathrm{C} ; 27.9$ $\mathrm{mm} ; 79 \%$; October $=24.2{ }^{\circ} \mathrm{C} ; 24.9 \mathrm{~mm} ; 74 \%$ and November $=25.4^{\circ} \mathrm{C} ; 4.7 \mathrm{~mm} ; 69 \%$.

The results obtained in the soil chemical and physical analyses, according to the methodology suggested by EMBRAPA (2009), in the 0-20 cm layer before experiment installation were the following for the chemical values: $\mathrm{pH}=$ 6.0; $\mathrm{P}=107.6 \mathrm{mg} \mathrm{dm}{ }^{-3} ; \mathrm{K}^{+}=85.4 \mathrm{mg} \mathrm{dm}^{-3} ; \mathrm{Na}^{+}=0.09 \mathrm{cmol}$ $\mathrm{dm}^{-3} ; \mathrm{H}^{+}+\mathrm{Al}^{+3}=0.41 \mathrm{cmol}_{\mathrm{c}} \mathrm{dm}^{-3} ; \mathrm{Al}^{+3}=0.00 \mathrm{cmol}_{\mathrm{c}} \mathrm{dm}^{-3} ; \mathrm{Ca}^{+2}=$
$2.78 \mathrm{cmol}_{\mathrm{c}} \mathrm{dm}^{-3} ; \mathrm{Mg}^{+2}=1.63 \mathrm{cmol}_{\mathrm{c}} \mathrm{dm}^{-3} ; \mathrm{SB} \mathrm{cmol}_{\mathrm{c}} \mathrm{dm}^{-3}=4.72$; organic matter $=11.64 \mathrm{~g} \mathrm{~kg}^{-1}$.

The experimental design was in randomized blocks, in a $6 \mathrm{x}$ 2 factorial scheme corresponding to six doses of cattle manure $\left(0 ; 10 ; 20 ; 30 ; 40\right.$ and $\left.50 \mathrm{tha}^{-1}\right)$, and presence and absence of nitrogen, with four repetitions. The plot consisted of 60 plants, arranged in three rows with 20 plants each, spaced by $0.20 \mathrm{~m}$ between rows and $0.10 \mathrm{~m}$ between plants.

For planting the crop in the field, seedlings were produced in conventional seed germination trays, with the cultivar Vale Ouro IPA-11, and transplanted 40 days after sowing. Basal fertilization consisted in supplying the doses of cattle manure and in the treatments with nitrogen, $120 \mathrm{~kg} \mathrm{ha}^{-1}$ of $\mathrm{N}$, in the form of ammonium sulfate, and split into equal parts applied at 20 and 40 days after transplanting (Filgueira, 2008).

Along the experimental period, cultural practices commonly used in onion crop were carried out, such as: manual weeding and supply of water in the period with absence of precipitation by the drip irrigation method (drip tape). It was not necessary to perform phytosanitary control, due to the absence of pests or diseases capable of causing economic damage to the crop.

Harvest was carried out around 100 days after transplanting, when the plants had advanced signs of senescence, such as yellow coloration and dried leaves and lodging in more than $70 \%$ of the plants. Then, the bulbs were subjected to the precure process (exposure of bulbs to the soil for four days) and transported to a shed, in order to determine the characteristics of production and classification of bulbs.

The characteristics evaluated were: shoot fresh and dry masses, with fresh mass corresponding to the mass of the plants before drying, and dry mass obtained in a forced air circulation oven at temperature of $65{ }^{\circ} \mathrm{C}$ for $96 \mathrm{~h}$; total and marketable yields of bulbs, which respectively corresponded to the weight of all bulbs harvested and to the weight of bulbs with mass considered marketable, with results extrapolated to $\mathrm{t} \mathrm{ha}^{-1}$; classification of bulbs based on their largest transverse diameter, according to the classification of Hortibrasil (2009), with results expressed as a percentage; leaf $\mathrm{N}$ concentration, by collecting one leaf per plant in each treatment and replicate at 60 days after transplanting. Leaf $\mathrm{N}$ concentration was determined by following the methodology proposed by Tedesco et al. (1995). Data were submited to analysis of variance and regression.

\section{Results AND Discussion}

There were interactive effects $(p \leq 0.05)$ of cattle manure and nitrogen doses on shoot fresh and dry masses, total and marketable yields, classification of bulbs according to their transverse diameter and on $\mathrm{N}$ concentration in onion bulbs.

According to Figure 1, the cattle manure dose of $50 \mathrm{t} \mathrm{ha}^{-1}$ with $\mathrm{N}$ led to maximum production of shoot fresh mass in onion, equal to 43.0 g plant $^{-1}$ at 80 days after transplanting (DAT). Without $\mathrm{N}$, the maximum shoot fresh mass production was 40.6 g plant $^{-1}$, at a dose of $43.0 \mathrm{t} \mathrm{ha}^{-1}$ of cattle manure, at $80 \mathrm{DAT}$.

Regardless of the treatments, the fresh mass production of onion plants increased over time, and the superiority at $80 \mathrm{DAT}$ in the treatments with cattle manure, both in the presence and in the absence of $\mathrm{N}$, is possibly due to the gradual enrichment of the soil with essential macro- and micronutrients for onion 


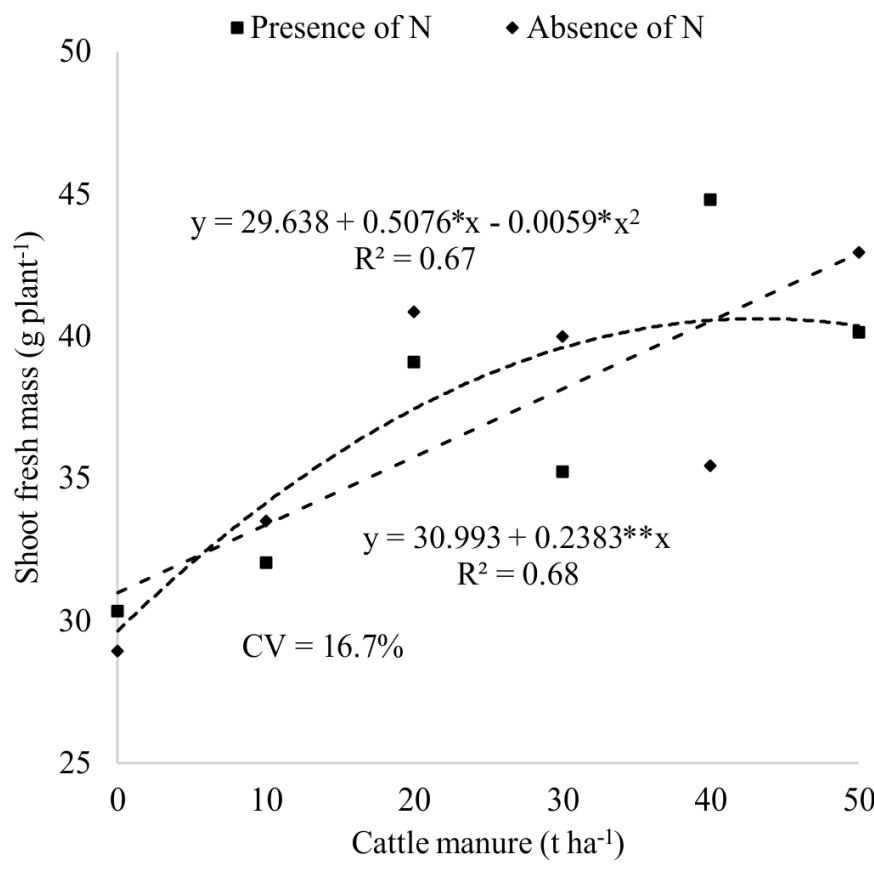

${ }^{*}$, ${ }^{* *}$ Significant at $\mathrm{p} \leq 0.05$ and $\mathrm{p} \leq 0.01$, respectively, by $\mathrm{F}$ test

Figure 1. Shoot fresh mass in onion fertilized with cattle manure in the presence and absence of nitrogen

and the progressive increase in the organic matter content of the soil (Trani et al., 2013).

Cattle manure at the dose of $50 \mathrm{t} \mathrm{ha}^{-1}$ associated with $\mathrm{N}$ led to dry mass production at $80 \mathrm{DAT}$ of $3.76 \mathrm{~g} \mathrm{plant}^{-1}$ (Figure 2). In this period, according to Vidigal et al. (2002), there is a greater growth of onion bulbs, and possibly there was a greater translocation of photoassimilates and redistribution of nutrients and other compounds to them, compromising the dry mass production. In the absence of $\mathrm{N}$ fertilization, the cattle manure dose of $30 \mathrm{t} \mathrm{ha}^{-1}$ promoted dry mass production of $3.5 \mathrm{~g} \mathrm{plant}^{-1}$ at 80 DAT (Figure 2). Marques et al. (2007) also observed higher dry mass production in marketable roots of beet under doses of cattle manure and nitrogen.

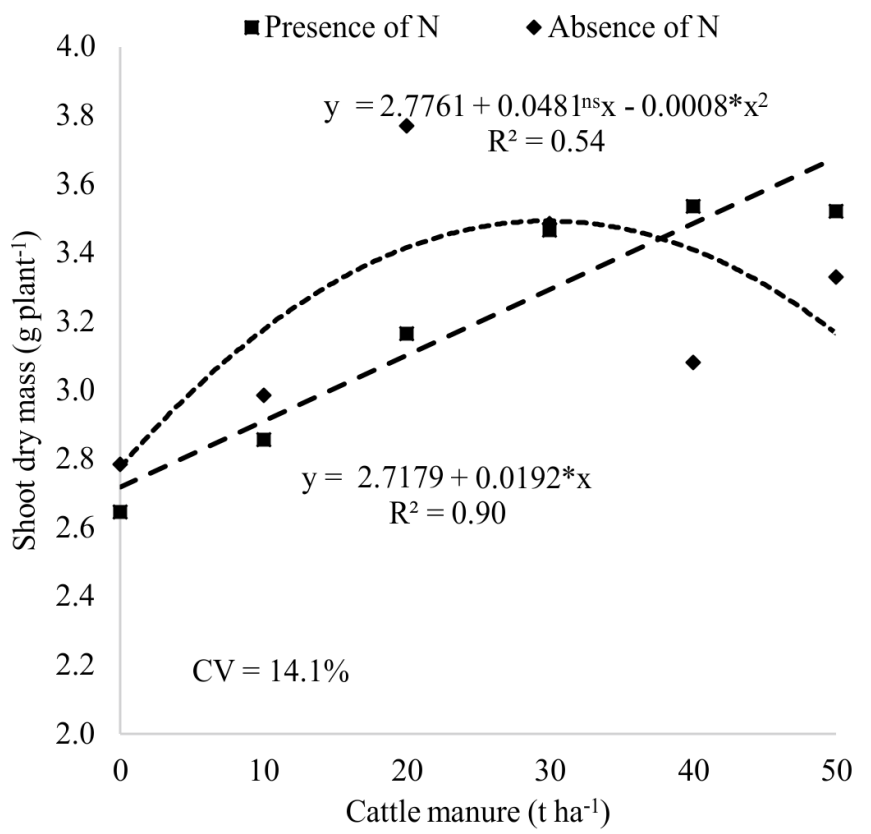

*, ** Significant at $\mathrm{p} \leq 0.05$ and $\mathrm{p} \leq 0.01$, respectively, by $\mathrm{F}$ test

Figure 2. Shoot dry mass in onion fertilized with doses of cattle manure in the presence and absence of nitrogen
The total yield of bulbs reached a maximum of $63.5 \mathrm{tha}^{-1}$ at the cattle manure dose of $28.8 \mathrm{t} \mathrm{ha}^{-1}$ in the presence of $\mathrm{N}$, whereas in its absence the data of total yield was not described by any model, with average value of $49.5 \mathrm{t} \mathrm{ha}^{-1}$ (Figure 3 )

These yields are below the range proposed by Vidigal et al. (2007), who affirm that in well-conducted onion crops the total yield in Brazil has varied between 40 and $60 \mathrm{t} \mathrm{ha}^{-1}$, or even higher.

The cattle manure dose of $27 \mathrm{tha}^{-1}$ in the presence of $\mathrm{N}$ was responsible for the maximum marketable bulb yield of $50 \mathrm{t}$ $\mathrm{ha}^{-1}$, whereas in the absence of $\mathrm{N}$ this yield was $36 \mathrm{tha}^{-1}$ at the dose of $28.2 \mathrm{tha}^{-1}$ (Figure 4). There was an increment of $14 \mathrm{t}$ $\mathrm{ha}^{-1}$ in the yield due to the presence of $\mathrm{N}$, but all yields were

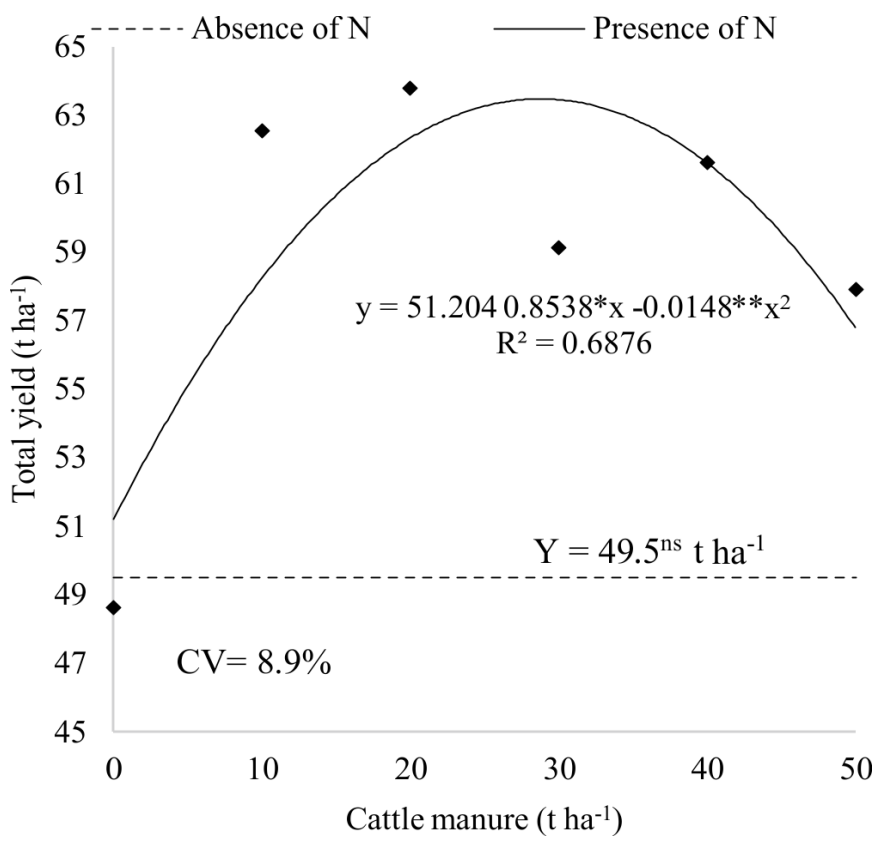

${ }^{*},{ }^{* *}$ Significant at $\mathrm{p} \leq 0.05$ and $\mathrm{p} \leq 0.01$, respectively, by $\mathrm{F}$ test; ${ }^{\text {s }}$ Not significant by $\mathrm{F}$ test Figure 3. Total yield of onion fertilized with doses of cattle manure in the presence and absence of nitrogen

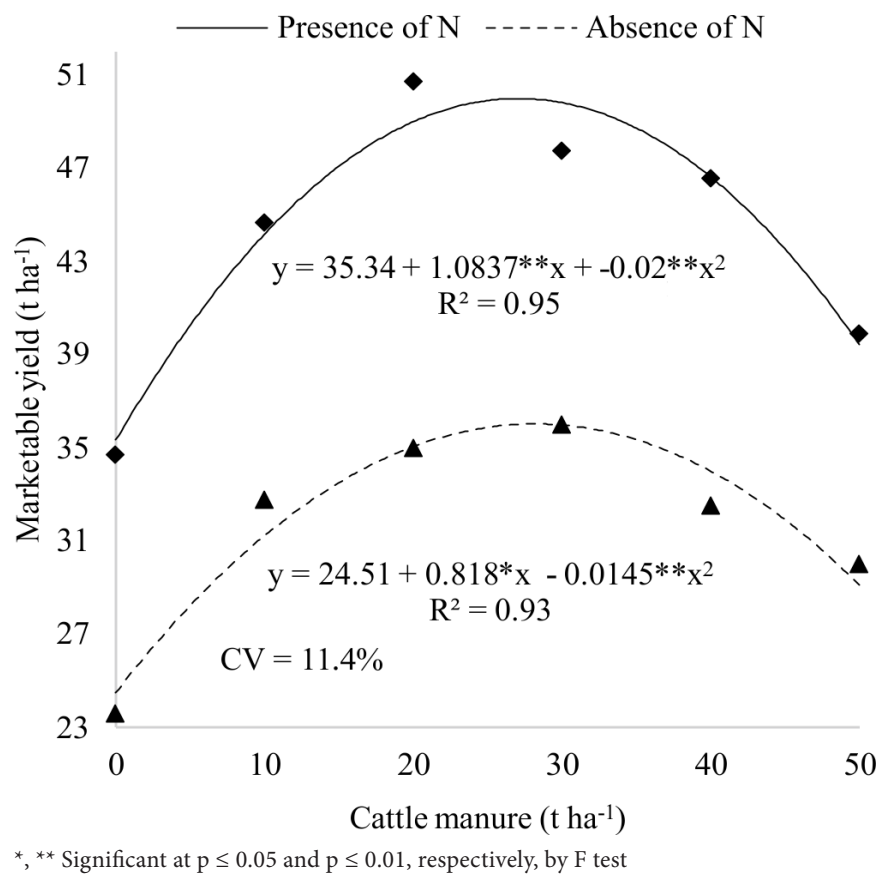

Figure 4. Marketable yield of onion fertilized with cattle manure in the presence and absence of nitrogen 
above the national average of $24 \mathrm{tha}^{-1}$ and the average of the Northeast region of $21 \mathrm{tha}^{-1}$ (IBGE, 2013).

These results demonstrate that the onion responded with increased production to the use of cattle manure, especially when associated with mineral nutrients, because this input can meet onion requirements for some nutrients and can be an alternative of fertilization for this species among small farmers who do not have financial capital to purchase chemical inputs but have cattle manure on their property. In addition, it may also reduce the use of chemical fertilizers, thus minimizing the contamination of the environment (Santos et al., 2006).

The effects of $\mathrm{N}$ on the increase of yield are probably due to its role in the vegetative growth, leaf formation and plant structure, besides being an alternative to increase yield, as it promotes increased leaf area index and production of vegetative and floral buds (Malavolta, 2006).

In the classification, there were no onion bulbs considered as waste (thick-stemmed, rotten, or with mechanical damage), demonstrating that the cattle manure with or without $\mathrm{N}$ was efficient in improving onion quality, and no regression model fitted to the data of Class 4 bulbs.

In relation to bulbs classified as Class 1 , the highest percentage was observed without the use of $\mathrm{N}, 70 \%$ with $14.5 \mathrm{t} \mathrm{ha}^{-1}$ of cattle manure, while in its presence the average percentage of bulbs was $14.96 \%$, as a function of the doses of cattle manure (Figure 5A). There was a reduction in the percentage of Class 2 bulbs with the use of $\mathrm{N}$, with a minimum of $33.6 \%$ at the cattle manure dose of $50 \mathrm{tha}^{-1}$. In the absence of $\mathrm{N}$, the percentage (90\%) of bulbs was increased up to the dose of $32.5 \mathrm{t} \mathrm{ha}^{-1}$ (Figure 5A). For onion, the highest commercial value of bulbs is located in Class 3 (Vidigal et al., 2010), so its higher percentage (32.5\%) was achieved with $26.2 \mathrm{t} \mathrm{ha}^{-1}$ of cattle manure combined with N (Figure 5B).

Bulbs classified in these classes (1 and 2) do not have good acceptance by the consumers, and the results may indicate that the use of $\mathrm{N}$ is important to improve onion quality. Resende et al. (2008) report that $\mathrm{N}$ application gradually reduces the production of bulbs with smaller diameters. May (2006) states that the application of N, P and K tends to reduce the quantities of bulbs with diameters outside the commercial standards. In relation to cattle manure, the increase in its use had a strong influence on the production of bulbs with larger diameter.

Bulbs belonging to Class 3 are well accepted in the consumer market and industries of sauces and seasonings (May, 2006). In the absence of $\mathrm{N}$, no regression model fitted to the data and an mean value of Class 3 bulbs was $11.07 \%$.

The maximum leaf $\mathrm{N}$ concentration in onion was $24.6 \mathrm{~g} \mathrm{~kg}^{-1}$ at the cattle manure dose of $27.2 \mathrm{tha}^{-1}$ in the presence of $\mathrm{N}$, whereas without this nutrient, the $\mathrm{N}$ concentration reached a maximum of $21.8 \mathrm{~g} \mathrm{~kg}^{-1}$ with $31.2 \mathrm{t} \mathrm{ha}^{-1}$ of cattle manure (Figure 6). The $\mathrm{N}$ concentration with cattle manure and $\mathrm{N}$ was $2.8 \mathrm{~g} \mathrm{~kg}^{-1}$ higher than

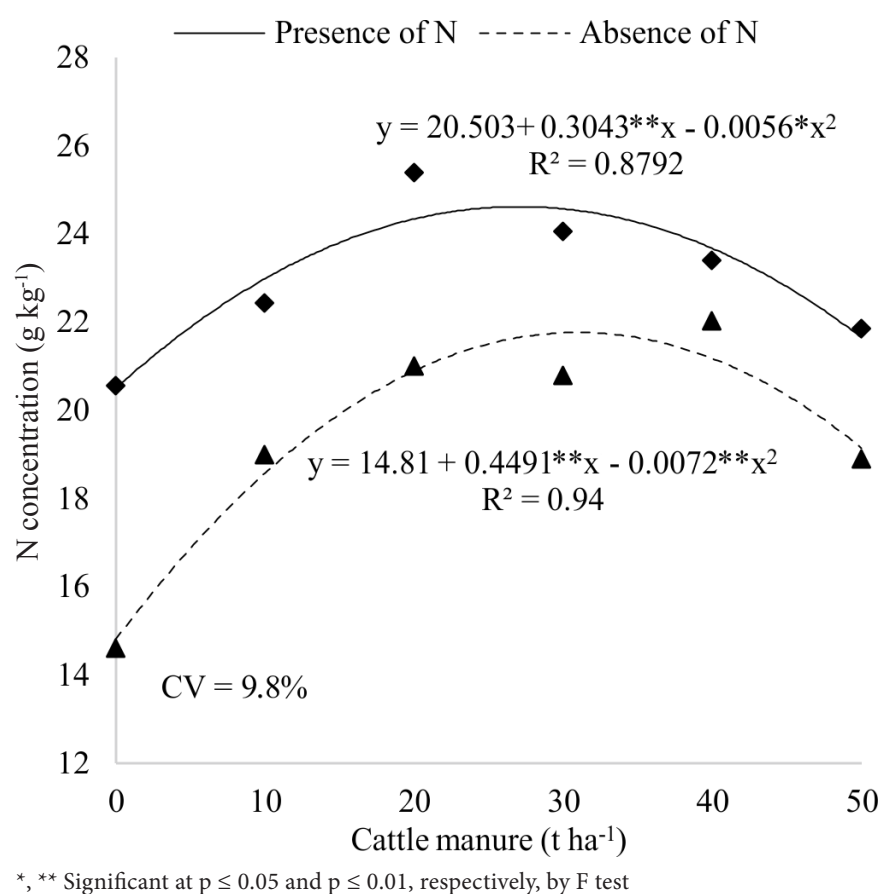

Figure 6. Leaf N concentration of onion fertilized with doses of cattle manure in the presence and absence of nitrogen
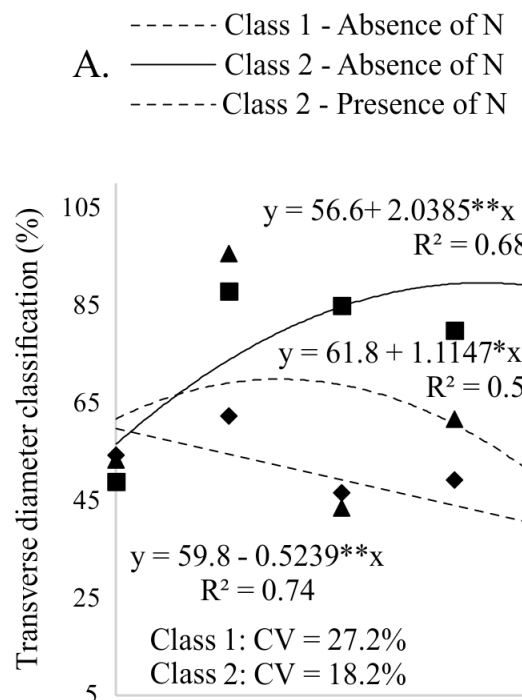

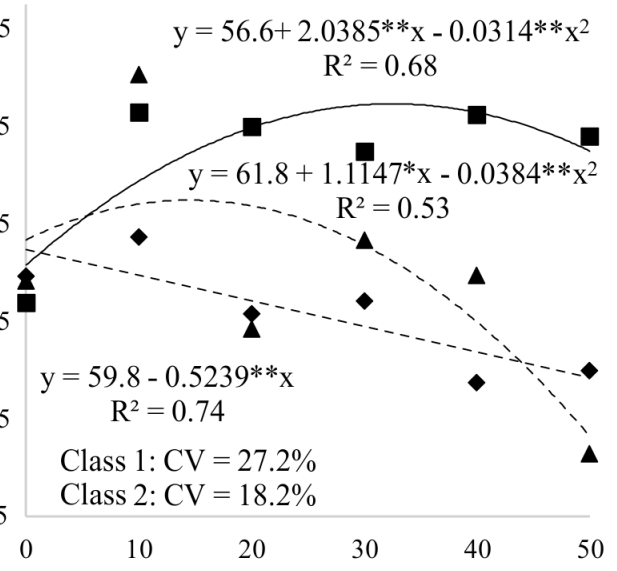

B. - Class 3 - Presence of $\mathrm{N}$

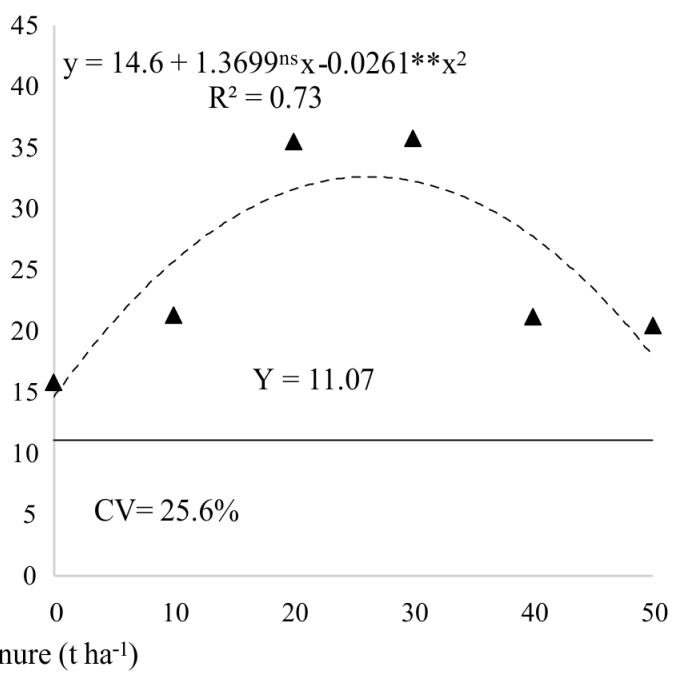

*, ** Significant at $\mathrm{p} \leq 0.05$ and $\mathrm{p} \leq 0.01$, respectively, by $\mathrm{F}$ test; ${ }^{\mathrm{n}} \mathrm{Not}$ significant by $\mathrm{F}$ test

Figure 5. Classification for bulb transverse diameter, Classes 1 and 2 (A) and Class 3 (B), in onion plants fertilized with doses of cattle manure in the presence and absence of nitrogen 
that obtained without nitrogen, but all concentrations were within the adequate range (between 19 and $40 \mathrm{~g} \mathrm{~kg}^{-1}$ ) for the species, (Jones Júnior et al., 1991; Caldwell et al., 1994).

\section{Conclusions}

1. Shoot fresh and dry masses, were altered by fertilization with cattle manure and nitrogen.

2. The marketable yield under experimental conditions exceeded the averages of Brazil and Northeast region.

3. Nitrogen increased the production of bulbs within the class of greater acceptance by the consumers.

4. Onion plants were adequately nourished with nitrogen.

5. The optimal dose for marketable yield of bulbs is $27 \mathrm{t}$ $\mathrm{ha}^{-1}$ of cattle manure in the presence of nitrogen.

\section{ACKNOWLeDgments}

To the Conselho Nacional de Desenvolvimento Científico e Tecnológico $(\mathrm{CNPq})$ for granting the scholarship and to the employees and colleagues of the Universidade Federal da Paraíba-UFPB.

\section{Literature Cited}

Araújo, E. N. de; Oliveira, A. P. de; Cavalcante, L. F.; Pereira, W. E.; Brito, N. M. de; Neves, C. M. de L.; Silva, E. E. da. Produção do pimentão adubado com esterco bovino e biofertilizante. Revista Brasileira de Engenharia Agrícola e Ambiental, v.11, p.466-470, 2007. https://doi.org/10.1590/S1415-43662007000500003

Caldwell, J. O. N.; Sumner, M. E.; Vavrina, C. S. Development and testing of preliminary foliar DRIS norms for onions. HortScience, v.29, p.1501-1504, 1994. https://doi.org/10.21273/ HORTSCI.29.12.1501

EMBRAPA - Empresa Brasileira de Pesquisa Agropecuária. Manual de análises químicas de solos, plantas e fertilizantes. Brasília: Embrapa Informação Tecnológica, 2009. 627p.

Filgueira, F. A. R. Manual de olericultura: Agrotecnologia moderna na produção e comercialização de hortaliças. 3.ed. Viçosa: UFV, 2008. 421p.

Gondim, A. W. A.; Fernandez, B. Probabilidade de chuvas para o município de Areia, PB. Agropecuária Técnica, v.1, p.55-63, 1980.

Hortibrasil - Normas de classificação impressas pelo Programa Brasileiro para a Modernização da Horticultura. São Paulo: Hortibrasil, 2009. Available on: < http://www.hortibrasil.org.br/ images/stories/folders/cebola.pdf> Accessed on: Oct. 2015.

IBGE - Instituto Brasileiro de Geografia e Estatística. Indicadores IBGE. 2013. Available on: <http://www.ibge.gov.br/home/ estatistica/indicadores/agropecuaria/lspa/estProdAgr_201309. pdf $>$. Accessed on: Nov. 2015.

Jones Junior, J. B.; Wolf, B.; Mills, H. A. Plant analysis an analysis handbook: A practical sampling, preparation, analysis and interpretation guide. Athens: Micro-Macro, 1991. 213p.

Malavolta, E. Manual de nutrição mineral de plantas. São Paulo: Ceres, 2006. 638p.
Marques, L. F.; Medeiros, D. C.; Araújo, W.; Lopes, R.; Teófilo, T. M. S.; Alves, S. S. V.; Oliveira, A. K.; Silva, J. C. V. Qualidade de beterraba em função de diferentes dosagens de esterco bovino. In: Congresso Brasileiro de Olericultura, 47, 2007, Porto Seguro. Resumos... Porto Seguro: ABH, 2007. CD-Rom

May, A. Desempenho de híbridos de cebola em função da população de plantas e fertilização nitrogenada e potássica. Jaboticabal: UNESP, 2006. 144p. Tese Doutorado

Oliveira, A. P.; Santos, J. F.; Cavalcante, L. F.; Pereira, W. E.; Santos, M. do C. C. A.; Oliveira, A. N. P.; Silva, N. V. Yield of sweet potato fertilized with cattle manure and biofertilizer. Horticultura Brasileira, v.28, p.277-281, 2010. https://doi.org/10.1590/S010205362010000300006

Pôrto, D. R. de Q.; Cecílio Filho, A. B.; May, A.; Vargas, P. F. Acúmulo de macronutrientes pela cultivar de cebola "Superex" estabelecida por semeadura direta. Ciência Rural, v.37, p.949-955. 2007. https://doi.org/10.1590/S0103-84782007000400005

Resende, G. M. de; Costa, N. D. Produtividade e armazenamento de cebola (Allium cepa) submetida a doses de nitrogênio e potássio via fertirrigação em cultivo de verão. Ciência e Agrotecnologia, v.33, p.1314-1320, 2009. https://doi.org/10.1590/S141370542009000500017

Resende, G. M. de; Costa, N. D.; Pinto, J. M. Produtividade e qualidade pós-colheita de cebola adubada com doses crescentes de nitrogênio e potássio. Horticultura Brasileira, v.26, p.388-392. 2008. https://doi.org/10.1590/1983-21252015v28n327rc

Rodrigues, G. S. O.; Grangeiro, L. C.; Negreiros, M. Z.; Silva, A. C.; Novo Júnior, J. Qualidade de cebola em função de doses de nitrogênio e épocas de plantio. Revista Caatinga, v.28, p.239-247, 2015. https://doi.org/10.1590/1983-21252015v28n327rc

Santos, J. F. dos; Oliveira, A. P. de; Alves, A. U.; Dornelas, C. S. M.; Brito, C. H. de; Nóbrega, J. P. R. Produção de batata-doce adubada com esterco bovino em solo com baixo teor de matéria orgânica. Horticultura Brasileira, v.24, p.103-106, 2006. https:// doi.org/10.1590/S0102-05362006000100021

Souza, R. J.; Resende, G. M. Cultura da cebola. Lavras: UFLA/ FAEPE, 2002. 115p.

Tedesco, M. J.; Gianello, C.; Bissani, C. A.; Bohnen, H.; Volkweiss, S. J. Análise de solo, planta e outros materiais. Porto Alegre: UFRGS, 1995. 174p.

Trani, P. E.; Terra, M. M.; Tecchio, M. A.; Teixeira, L. A. J.; Hanasiro, J. Adubação orgânica de hortaliças e frutíferas. Campinas: Instituto Agronômico de Campinas, 2013. 16p.

Vidigal, S. M.; Costa, E. L.; Ciociola Júnior, A. I. Cebola (Allium cepa L.). In: Paula Junior, T. J.; Venzon, M. (eds.). 101 Culturas: Manual de tecnologias agrícolas. Belo Horizonte: EPAMIG, 2007. p.243-252.

Vidigal, S. M.; Pedrosa, M. W.; Fonseca, M. S.; Santos, I. C. Adubação com nitrogênio em cobertura na produção de cebola. Horticultura Brasileira, v.28, p.3705-3711, 2010. https://doi.org/10.1590/S010205362010000200005

Vidigal, S. M.; Pereira, P. R. G.; Pacheco, D. D. Nutrição mineral e adubação de cebola. Informe Agropecuário, v.23, p.36-50.2002. 